Open Access at : http://jurnal.umt.ac.id/index.php/replik/article/view/1447

\title{
KEPASTIAN HUKUM ITSBAT NIKAH DALAM HUKUM PERKAWINAN
}

\author{
Farida Nurun Nazah \\ Husnia \\ Fakultas Hukum Universitas Muhammadiyah Tangerang \\ E-mail : farida_bachri@yahoo.com
}

\begin{abstract}
Abstrak
Itsbat Nikah merupakan salah satu bentuk perlindungan hukum dalam perkawinan karena menjamin kepastian hukum terhadap status perkawinan, status anak dan harta bersama. Status perkawinan dimaksud adalah aspek legalitas formil menurut Undang-Undang Nomor 1 Tahun 1974. Menurut aturan yuridis, perkawinan yang tidak dicatatkan dapat mengajukan permohonan Itsbat Nikah ke Pengadilan Agama selama praktek perkawinan tersebut tidak menyimpang dari ketentuan Hukum Islam. Kompilasi Hukum Islam yang lahir berdasarkan Instruksi Presiden Nomor 1 Tahun 1991 menyatakan bahwa salah satu syarat dikabulkan Itsbat Nikah adalah adanya perkawinan yang terjadi sebelum berlakunya Undang-Undang Nomor 1 Tahun 1974. Namun faktanya, hasil penelitian menemukan bahwa Pengadilan Agama lebih banyak mengabulkan Itsbat Nikah pasca disahkan Undang-Undang Perkawinan dari pada sebelum disahkan Undang-Undang Perkawinan. Penelitian ini hadir untuk memberikan pemahaman kepada msyarakat supaya tidak menyalahgunakan perlindungan hukum berupa Itsbat Nikah.
\end{abstract}

\section{Pendahuluan}

Istilah lain dari kepastian hukum adalah principle of legal security dan rechtszekerheid, merupakan perangkat hukum suatu negara yang mampu menjamin hak dan kewajiban setiap warga negara. Kepastian hukum (rechtszekerheid) juga diartikan sebagai jaminan bagi anggota masyarakat, bahwa 
semuanya akan diperlakukan oleh negara/penguasa berdasarkan peraturan hukum, tidak dengan sewenang-wenang.

Itsbat Nikah sebagai pengesahan perkawinan tidak berarti perkawinan yang telah dilaksanakan suami dan istri tidak sah sepanjang memenuhi rukun dan syarat perkawinan menurut hukum Islam. Itsbat Nikah adalah proses hukum yang harus ditempuh oleh pasangan suami dan istri di Pengadilan Agama, agar "perkawinan tidak dicatat" yang telah sah menurut hukum agama (islam), tetapi kemudian menjadi "perkawinan dicatat" secara hukum negara. ${ }^{1}$

Adapun ketentuan yang terkandung dalam ayat (2), mengatur masalah norma hukum. Untuk kepentingan ketertiban sebuah keluarga yang merupakan unit terkecil dari suatu negara, pemerintah menganggap perlu terlibat dan campur tangan mewujudkan rumah tangga yang harmonis dan berkeadilan, sehingga pemeran keluarga itu yang terdiri dari suami, istri dan anak-anak memiliki hak yang dijamin oleh Undang-Undang serta kewajiban yang harus ditunaikan. Untuk mewujudkan hal tersebut, maka setiap perkawinan harus dicatatkan di Pegawai Pencatat Nikah. Perkawinan semacam inilah yang dipandang oleh hukum sebagai perkawinan yang legal dan diakui. Adapun perkawinan yang mengabaikan ketentuan ayat diatas, maka perkawinan tersebut dipandang tidak legal dan tidak diakui. Dan lebih spesifik lagi, bahwa perkawinan yang tidak memenuhi ketentuan ayat (2) tersebut dipandang sebagai perkawinan sirri. ${ }^{2}$

Ada beberapa kelemahan tidak dipenuhinya norma hukum dalam suatu perkawinan. Pertama, apabila suatu saat terjadi ketidak harmonisan dalam rumah tangga, maka pihak yang merasa dirugikan hak-haknya tidak dapat memperoleh haknya itu melalui kekuatan Negara yakni lembaga peradilan, sehingga bagi suami istri tersebut berlaku hukum rimba, dan biasanya yang kuat adalah pihak laki-laki, sehingga yang menjadi korban adalah pihak istri. Kedua, bagi anak-anak akan memerlukan bukti kelahiran berupa akta dan surat-surat keterangan lainnya yang diperlukan akan menemui kesulitan jika kedua orang tuanya tidak

1 Muhammad Syaifuddin, Sri Turatmiyah dan Annalisa Yahanan, Hukum Perceraian, (Jakarta : Sinar Grafika, 2013), hlm. 272

2 Anshary, Kedudukan Anak Dalam Perspektif Hukum Islam Dan Hukum Nasional, (Bandung : CV. Mandar Maju, 2014), hlm. 127-128 
mempunyai bukti resmi tentang perkawinan mereka. Ketiga, tuntutan keperdataan lain, seperti tuntutan hak waris, tuntutan pemeliharaan anak dan sebagainya tidak akan dapat diselesaikan melalui lembaga Pengadilan jika pasangan suami istri tidak mempunyai bukti resmi tentang perkawinan mereka. Oleh sebab itu nikah sirri harus dihindari. ${ }^{3}$

Kehadiran qadhi liar yang mengawinkan pasangan suami istri secara illegal merupakan salah satu faktor menjamurnya praktik kawin sirri di Indonesia. Terdapat di banyak daerah di Indonesia adanya qadhi liar yang usahanya memang mengawinkan orang secara liar, tidak memperhatikan rukun-rukun nikah untuk sahnya suatu perkawinan dan juga tidak memperhatikan hukum Negara. Mengawinkan orang merupakan bisnis, karena mata pencahariannya hanya itu. Mereka yang mendapat julukan qadhi liar ini pada umumnya orang yang mendapat predikat ustadz, kiai, buya atau tuan guru. Perkawinan semacam ini disamping tidak sah menurut ajaran agama juga dipandang tidak mempunyai kekuatan hukum (no legal force) oleh Negara. Di Indonesia, perkawinan semacam itu tidak dilindungi oleh hukum. ${ }^{4}$

Adapun perkawinan yang dilakukan secara sirri atau di bawah tangan (tidak dicatatkan) tetapi telah memenuhi ketentuan Pasal 2 ayat (1) UU Nomor 1 Tahun 1974 yang dilaksanakan setelah tahun 1974 dimana situasi negara atau daerah tempat perkawinan dilaksanakan kondusif serta Kantor Pencatat Nikah berfungsi sebagaimana biasa, maka perkawinan semacam ini tidak dapat dimohonkan Itsbat Nikah (pengesahan nikah) ke pengadilan, juga tidak dapat didaftarkan ke Kantor Pencatat Nikah untuk dicatatkan. Sebab tidak dipenuhinya ketentuan Pasal 2 ayat (2) tersebut bukan karena situasi atau kondisi yang memaksanya sehingga perkawinannya tidak dapat dicatatkan ke Kantor Pencatat Nikah, melainkan karena lebih ditentukan oleh faktor ketidaktaatan kedua calon mempelai terhadap hukum alias tidak patuh hukum. Dan terhadap orang yang tidak patuh hukum, maka perbuatan hukum yang dilakukannya tersebut layak untuk tidak mendapat perlindungan hukum (no legal protect), dan hukum memandangnya sebagai

\footnotetext{
${ }^{3}$ Ibid, hlm. 131-132

${ }^{4}$ Ibid. hlm. 133-134
} 
perbuatan yang tidak mempunyai kekuatan hukum (no legal force), sebagaimana bunyi Pasal 6 ayat (2) Kompilasi Hukum Islam, "Perkawinan yang dilakukan di luar pengawasan Pegawai Pencatat Nikah tidak mempunyai kekuatan hukum”.

Pasal 7 Kompilasi Hukum Islam mengatur sebagai berikut:

1. Perkawinan hanya dapat dibuktikan dengan Akta Nikah yang dibuat oleh Pegawai Pencatat Nikah;

2. Dalam hal perkawinan tidak dapat dibuktikan dengan Akta Nikah, dapat diajukan itsbat nikahnya ke Pengadilan Agama;

3. Itsbat nikah yang dapat diajukan ke Pengadilan Agama terbatas mengenai hal-hal yang berkenaan dengan:

a. Adanya perkawinan dalam rangka penyelesaian perceraian;

b. Hilangnya Akta Nikah;

c. Adanya keraguan tentang sah atau tidaknya salah satu syarat perkawinan;

d. Adanya perkawinan yang terjadi sebelum berlakunya UU Nomor 1 Tahun 1974;

e. Perkawinan yang dilakukan oleh mereka yang tidak mempunyai halangan perkawinan menurut UU Nomor 1 Tahun $1974 .^{5}$

Perkawinan yang dapat dimohonkan Itsbat Nikah ke Pengadilan hanyalah perkawinan yang sah yang dilakukan sebelum tahun 1974, maka pengadilan harus menyatakan tidak berwenang mengitsbatkannya karena tidak mempunyai dasar hukum. Dan jika pun pengadilan mengitsbatkannya, maka penetapan pengadilan tersebut harus dinyatakan batal demi hukum (van rechtswege). ${ }^{6}$ Namun kenyataannya, pasca diberlakukan Undang-Undang Perkawinan-pun masih banyak masyarakat yang melakukan upaya hukum berupa Itsbat Nikah ke Pengadilan Agama dengan berbagai alasan hukum yang melatarbelakangi.

Maka dari itu, penelitian ini dilakukan untuk memberikan pemahaman konkrit terhadap pelaksanaan Itsbat Nikah pasca disahkan Undang-Undang Perkawinan.

\footnotetext{
${ }^{5}$ Ibid, hlm. 138-139

${ }^{6}$ Ibid. hlm. 140
} 


\section{Pembahasan}

\section{Kebijakan Regulasi}

Kewenangan Pengadilan Agama di bidang perkawinan diatur dalam penjelasan Pasal 49 Ayat (2) Undang-Undang Nomor 7 Tahun 1989 yang telah diubah dengan Undang-Undang Nomor 3 Tahun 2006 dan terakhir diubah dengan Undang-Undang Nomor 50 Tahun 2009 tentang Peradilan Agama, dirinci menjadi 22 (dua puluh dua) jenis perkara. Dari 22 jenis perkara itu ada yang berupa gugatan (kontentius) ada pula yang berupa permohonan (voluntair). Salah satu perkara permohonan (voluntair) yang menjadi kewenangan Pengadilan Agama adalah Itsbat Nikah. Namun kemudian kewenangan ini berkembang dan diperluas dengan digunakannya ketentuan Kompilasi Hukum Islam (KHI) Pasal 7 ayat (2) dan (3).

Ketentuan dan dasar hukum yang menjadi landasan yuridis bagi Pengadilan Agama untuk melakukan Itsbat Nikah adalah penjelasan Pasal 49 Ayat (2) angka 22 dan Pasal 7 Ayat (2) dan Ayat (3) huruf d Kompilasi Hukum Islam. Sedangkan kedua ketentuan tersebut membatasi perkawinan yang dapat dimohonkan Itsbat ke Pengadilan Agama hanya perkawinan yang dilangsungkan sebelum berlakunya Undang-Undang Nomor 1 Tahun 1974 tentang Perkawinan.

Dalam Kompilasi Hukum Islam Pasal 4 disebut sahnya perkawinan bila dilakukan menurut Hukum Islam. Pada Pasal 5 ditegaskan bahwa setiap perkawinan harus dicatat oleh Pegawai Pencatat Nikah. Karena itu, dalam Pasal 6 dinyatakan bahwa setiap perkawinan harus dilangsungkan di hadapan dan di bawah pengawasan Pegawai Pencatat Nikah. Dan perkawinan yang dilakukan di luar pengawasan pencatat nikah tidak mempunyai kekuatan hukum. Di dalam Pasal 7 disebutkan bahwa perkawinan hanya dapat dibuktikan dengan Akta Nikah yang dibuat oleh Pegawai Pencatat Nikah. ${ }^{7}$ Dalam Pasal 7 ayat 2 dan seterusnya dimungkinkan bagi mereka membuktikan perkawinannya dengan Akta Nikah dapat mengajukan “Itsbat Nikah" nya ke Pengadilan Agama. ${ }^{8}$

\footnotetext{
${ }^{7}$ Mohammad Daud Ali, Hukum Islam, (Jakarta: PT. Raja Grafindo Persada, 2004), hlm. 298

8 Abdurrahman, Kompilasi Hukum Islam Di Indonesia, (Jakarta: Akademika Pressindo, 2010), hlm. 69
} 
Namun karena Itsbat Nikah sangat dibutuhkan oleh masyarakat, maka hakim Pengadilan Agama melakukan "ijtihad" dengan menyimpangi tersebut, kemudian mengabulkan permohonan Itsbat Nikah berdasarkan ketentuan Pasal 7 Ayat (3) huruf e Kompilasi Hukum Islam, Apabila perkawinan yang dimohonkan untuk diitsbatkan itu tidak ada halangan perkawinan sebagaimana diatur di dalam Undang-Undang Nomor 1 Tahun 1974 tentang Perkawinan, maka Pengadilan Agama akan mengabulkan permohonan Itsbat Nikah meskipun perkawinan itu dilaksanakan pasca berlakunya Undang-Undang Nomor 1 Tahun 1974 tentang Perkawinan. Padahal, Kompilasi Hukum Islam (KHI) tidak termasuk dalam hierarki Peraturan PerUndang-Undangan yang disebutkan dalam Pasal 7 UndangUndang Nomor 10 Tahun 2004 tentang Pembentukan Peraturan PerUndangUndangan. Oleh karena itu, penetapan Itsbat Nikah oleh Pengadilan Agama tersebut, tidak lebih hanya sebagai kebijakan untuk mengisi kekosongan hukum yang mengatur tentang Itsbat Nikah terhadap perkawinan yang dilaksanakan pasca berlakunya Undang-Undang Nomor 1 Tahun 1974 tentang Perkawinan.

Kebijakan tersebut diambil karena ternyata Itsbat Nikah oleh Pengadilan Agama itu karena pertimbangan mashlahah bagi umat Islam. Itsbat Nikah sangat bermanfaat bagi umat Islam untuk mengurus dan mendapatkan hak-haknya yang berupa surat-surat atau dokumen pribadi yang dibutuhkan dari instansi yang berwenang serta memberikan jaminan perlindungan kepastian hukum terhadap masing-masing pasangan suami istri, termasuk perlindungan terhadap status anak yang lahir dari perkawinan itu, dan perlindungan terhadap akibat hukum yang akan muncul kemudian.

Status perkawinan dalam hal ini diartikan dengan keadaan dan kedudukan perkawinan yang telah dilangsungkan. Dalam aspek ini sebenarnya UndangUndang telah memberikan rumusan tentang perkawinan yang sah. Pasal 2 Ayat 1 Undang-Undang Nomor 1 Tahun 1974 Tentang Perkawinan menyebutkan bahwa perkawinan adalah sah, apabila dilakukan menurut hukum masing-masing agamanya dan kepercayaannya itu. Dalam penjelasan Pasal 2 disebutkan bahwa Dengan perumusan pada Pasal 2 ayat (1) ini, tidak ada Perkawinan diluar hukum rnasing-masing agamanya dan kepercayaannya itu, sesuai dengan Undang- 
Undang Dasar 1945. Yang dimaksud dengan hukum masing-masing agamanya dan kepercayaannya itu termasuk ketentuan PerUndang-Undangan yang berlaku bagi golongan agamanya dan kepercayaannya itu sepanjang tidak bertentangan atau tidak ditentukan lain dalam Undang-Undang ini. Berdasarkan ketentuan Pasal 2 Ayat 1 Undang-Undang Perkawinan dan penjelasannya ini, dapat diketahui bahwa patokan untuk mengetahui suatu perkawinan sah adalah hukum masingmasing agama dan kepercayaan para pihak serta ketentuan PerUndang-Undangan yang berlaku sepanjang tidak bertentangan atau tidak ditentukan lain dalam Undang-Undang Perkawinan. Pasal 2 ayat (2) menyebutkan bahwa tiap-tiap perkawinan dicatat menurut Peraturan PerUndang-Undangan yang berlaku. Pencatatan perkawinan akan menimbulkan kemaslahatan umum karena dengan pencatatan ini akan memberikan kepastian hukum terkait dengan hak-hak suami/isteri, kemaslahatan anak maupun efek lain dari perkawinan itu sendiri. Perkawinan yang dilakukan di bawah pengawasan atau di hadapan Pegawai Pencatat Nikah/Kantor Urusan Agama akan mendapatkan Akta Nikah sebagai bukti telah dilangsungkannya sebuah perkawinan.

Sejauh materi Undang-Undang Perkawinan yang diatur dalam Kompilasi Hukum Islam, Pengaturannya mengikuti rumusan yang terdapat dalam UndangUndang dan ditambahkan pasal-pasal lain yang tidak terdapat dalam UndangUndang sebagai pelengkap terhadap materi Undang-Undang Perkawinan. Sejauh yang mengatur secara langsung materi perkawinan dalam Undang-Undang Perkawinan tidak ada yang luput dari Kompilasi Hukum Islam. ${ }^{9}$

\section{Prosedur Itsbat Nikah}

Perkara pengesahan Itsbat Nikah adalah adanya perkawinan yang dilangsungkan berdasarkan agama atau tidak dicatat Pegawai Pencatat Nikah (PPN) yang berwenang yang diajukan oleh suami istri atau salah satu dari suami atau istri, anak, wali nikah dan pihak yang berkepentingan dengan perkawinan

9 Amir Syarifuddin, Hukum Perkawinan Islam Di Indonesia, (Jakarta: Kencana Prenada Media Group, 2011), hlm. 33 
tersebut yang diajukan kepada pengadilan tempat tinggal Pemohon dengan menyebutkan alasan dan kepentingan yang jelas.

Apabila suatu kehidupan suami istri berlangsung tanpa Akta Nikah karena adanya sesuatu sebab, Kompilasi Hukum Islam membuka kesempatan kepada mereka untuk mengajukan permohonan Itsbat Nikah (penetapan nikah) kepada Pengadilan Agama sehingga yang bersangkutan mempunyai kekuatan hukum dalam ikatan perkawinannya. Permohonan Itsbat Nikah menurut Pasal 7 ayat (4) Kompilasi Hukum Islam menyatakan bahwa yang berhak mengajukan permohonan Itsbat nikah ialah suami atau istri, anak-anak mereka, wali nikah dan pihak yang berkepentingan dengan perkawinan itu. ${ }^{10}$

Adapun prosedur pengajuan Itsbat Nikah ke Pengadilan Agama sama halnya dengan prosedur-prosedur pengajuan perkara perdata yang lain, yaitu sebagaimana di jelaskan didalam buku Peradilan Agama Di Indonesia di paparkan secara jelas tentang tata cara berperkara di pengadilan Agama yaitu:

\section{a. Datang dan Mendaftar ke Kantor Pengadilan Agama}

1) Mendatangi Kantor Pengadilan Agama di wilayah tempat tinggal Pemohon untuk menyatakan bahwa dirinya ingin mengajukan permohonan. Permohonan dapat diajukan dalam bentuk surat atau secara lisan, atau juga dapat dengan menggunakan kuasa yang telah ditunjuk kepada ketua Pengadilan Agama dengan membawa surat bukti identitas diri (KTP).

2) Membuat surat permohonan Itsbat Nikah dapat dibuat sendiri. Apabila tidak bisa membuat surat permohonan, dapat meminta bantuan kepada Pos Bakum (Pos Bantuan Hukum) yang ada pada pengadilan setempat secara cuma-cuma. Surat permohonan tidak ada lawan sudah dibuat tertulis oleh pemohon untuk mendaftarkan di Kepaniteraan Pengadilan Agama daerah hukum kediaman pemohon (wilayah tempat tinggalnya) dilengkapi dengan syarat kelengkapan umum, ${ }^{11}$ berupa surat permohonan (dalam pengertian asli), supaya dibuat sesuai dengan prinsipnya, yaitu

\footnotetext{
${ }^{10}$ Zainuddin Ali, Hukum Perdata Islam Di Indonesia, (Jakarta: Sinar Grafika, 2012), hlm. 29

${ }^{11}$ Erfaniah Zuhriah, Peradilan Agama di Indonesia, (Malang: UIN Malang Press, 2008), hlm. 240
} 
tidak ada lawan, itulah yang pokok. Jadi bentuknya tidak jauh dari bentuk surat gugatan, tapi tidak ada lawan. Dengan demikian identitas pihak hanyalah pihak pemohon saja. ${ }^{12}$

3) Memfotokopi formulir permohonan Itsbat Nikah sebanyak 5 rangkap, kemudian mengisinya dan menandatangani formulir yang telah lengkap. Empat rangkap formulir permohonan diserahkan kepada petugas Pengadilan, satu fotokopi di simpan oleh Pemohon.

4) Melampirkan surat-surat yang diperlukan, antara lain surat keterangan dari Kantor Urusan Agama bahwa pernikahannya tidak tercatat.

5) Pendaftaran perkara diajukan kepada Pengadilan Agama melalui kepaniteraan di Meja I untuk ditetapkan biaya perkara (SKUM).

6) Pemohon wajib membayar uang muka atau biaya ongkos berperkara (pasal 121 ayat (4) HIR).

7) Pemohon membayar Panjar Biaya Perkara (PBP) yang sudah ditentukan oleh Ketua Pengadilan di pemegang kas Meja I. Bagi yang tidak mempunyai kemampuan untuk membayar uang perkara, Pengadilan Agama menyediakan jalan keluar dengan adanya prodeo (cuma-cuma). Permohonan perkara prodeo ini ditulis dalam surat permohonan bersamasama (menjadi satu) dengan permohonan Itsbat Nikah. Selanjutnya berkas diberi nomor perkara permohonan tanda $\mathrm{P}$.

8) Panitera pendaftaran perkara menyampaikan permohonan kepada bagian berperkara sehingga permohonan secara resmi dapat diterima dan didaftarkan dalam buku register.

9) Setelah didaftarkan, permohonan diteruskan kepada Ketua Pengadilan Agama dan diberi catatan mengenai nomor, tanggal perkara dan ditentukan hari sidangnya.

10) Pemohon menyerahkan kelengkapan berkas perkara dan SKUM yang telah dibayar di Meja II untuk pengadministrasian. ${ }^{13}$

11) Berkas diserahkan ke meja III untuk dibukukan.

${ }^{12}$ Roihan A. Rasyid, Loc. Cit., hlm. 67

${ }^{13}$ Jaih Mubarok, Peradilan Agama di Indonesia, (Jakarta: Pustaka Bani Quraish, 2004), hlm. 
Oleh panitera, selanjutnya dilakukan tahapan sebagai berikut:

1) Berkas diserahkan kepada Ketua Pengadilan Agama.

2) Selanjutnya dilakukan Penetapan Majelis Hakim (PMH) oleh Ketua Pengadilan yang terdiri satu orang hakim sebagai ketua majelis dan dua orang hakim sebagai hakim anggota serta panitera sidang untuk memeriksa, memutus, dan mengadili perkara.

3) Penunjukan Panitera Pengganti oleh Panitera untuk membantu Majelis Hakim supaya menghadiri, mencatat jalannya Sidang Pengadilan, membuat Berita Acara Persidangan dan Penetapan.

4) Penetapan Hari Sidang (PHS) oleh Ketua Majelis.

5) Panitera sidang dibantu juru sita akan melakukan pemanggilan kepada pihak-pihak yang berperkara (di tempat tinggalnya) untuk menghadiri sidang sesuai dengan hari, tanggal sekurang kurangnya 3 hari sebelum sidang, jam dan tempat yang ditunjuk dalam PHS.

6) Diberitahukan pada pemohon dapat mempersiapkan saksi-saksi dan bukti-bukti yang diajukan dalam persidangan.

7) Bukti bahwa para pihak telah dipanggil secara patut berupa berita acara yang disampaikan kepada Majelis Hakim yang memeriksa perkara.

Tiap pemeriksaan perkara di Pengadilan, dimulai sesudah diajukan suatu permohonan. Kemudian berdasar permohonan pihak-pihak yang berperkara dipanggil untuk menghadiri pemeriksaan di sidang pengadilan sesuai dengan nomor urutnya. ${ }^{14}$

\section{b. Menghadiri Persidangan}

1) Datang ke Pengadilan sesuai dengan tanggal dan waktu yang tertera dalam surat panggilan. Upayakan untuk datang tepat waktu dan jangan terlambat.

14 M. Yahya Harahap, Kedudukan Kewenangan dan Acara Peradilan Agama, cet. III, (Jakarta: Pustaka Kartini, 1997), hlm. 145 
2) Hakim ketua atau anggota majelis Hakim (yang akan memeriksa perkara) memeriksa kelengkapan surat permohonan.

3) Panitera memanggil para Pemohon dengan membawa surat panggilan sidang secarat patut.

4) Semua proses pemeriksaan perkara dicatat dalam Berita Acara Persidangan (BAP).

5) Untuk sidang pertama, bawa serta dokumen seperti Surat Panggilan Persidangan, fotokopi formulir permohonan yang telah diisi. Dalam sidang pertama ini hakim akan menanyakan identitas para Pihak misalnya KTP atau kartu identitas lainnya yang asli. Dalam kondisi tertentu hakim kemungkinan akan melakukan pemeriksaan isi permohonan.

6) Untuk sidang selanjutnya, hakim akan memberitahukan kepada Pemohon/Termohon yang hadir dalam sidang kapan tanggal dan waktu sidang berikutnya. Bagi Pemohon/Termohon yang tidak hadir dalam sidang, untuk persidangan berikutnya akan dilakukan pemanggilan ulang kepada yang bersangkutan melalui surat.

7) Untuk sidang kedua dan seterusnya, ada kemungkinan Pemohon harus mempersiapkan dokumen dan bukti sesuai dengan permintaan hakim. Dalam kondisi tertentu, hakim akan meminta Pemohon menghadirkan saksi-saksi yaitu orang yang mengetahui pernikahan para Pemohon diantaranya wali nikah dan saksi nikah, atau orang-orang terdekat yang mengetahui pernikahan para Pemohon.

\section{c. Putusan/Penetapan Pengadilan}

1) Jika permohonan dikabulkan, Pengadilan akan mengeluarkan putusan/penetapan Itsbat Nikah.

2) Salinan putusan/penetapan Itsbat Nikah akan siap diambil dalam jangka waktu setelah 14 hari dari sidang terakhir.

3) Salinan putusan/penetapan Itsbat Nikah dapat diambil sendiri ke kantor Pengadilan atau mewakilkan kepada orang lain dengan Surat Kuasa. 
4) Setelah mendapatkan salinan putusan/penetapan tersebut, bisa meminta Kantor Urusan Agama setempat untuk mencatatkan pernikahan dengan menunjukkan bukti salinan putusan/penetapan pengadilan tersebut.

\section{Syarat Sah Itsbat Nikah}

Pengesahan telah diatur di dalam Pasal 64 Undang-Undang Nomor 1 Tahun 1974 dan Peraturan Menteri Agama Tahun 1990. Perkara ini termasuk dalam perkara permohonan yang merupakan kekuasaan absolut (jenis perkara) Peradilan Agama yang merupakan perkara voluntair yang tidak mengandung sengketa dan hanya ada pihak pemohon saja. ${ }^{15}$ Permohonan Itsbat Nikah atau Pengesahan Nikah ialah permohonan yang diajukan kepada Pengadilan Agama agar suami istri yang telah melaksanakan perkawinan yang disebutkan dalam permohonan dinyatakan sah oleh Pengadilan Agama.

Itsbat Nikah mengandung makna penetapan perkawinan melalui pencatatan perkawinan oleh pejabat yang berwenang berdasarkan Peraturan PerUndangUndangan. Pejabat berwenang yang dimaksud adalah Pegawai Pencatat Nikah (PPN) yang berada di wilayah hukum calon mempelai yang akan melangsungkan Hukum Perkawinan. ${ }^{16}$

Aturan Pengesahan nikah/Itsbat Nikah dibuat atas dasar adanya sebuah peristiwa perkawinan yang dilangsungkan berdasarkan aturan yang ditentukan oleh Agama akan tetapi tidak memenuhi persyaratan yang di atur oleh Negara yaitu tidak dicatat oleh PPN yang berwenang.

Untuk pengesahan nikah diperlukan persyaratan diantaranya wali yang sah, dua orang saksi yang menyaksikan terjadinya pernikahan dan sebutan "mahr" atau mas kawin. Tetapi bilamana tidak ada dua orang saksi itu, dapat dicukupkan dengan pernyataan dari wanita yang baligh disertai sumpah bahwa ia telah nikah sesuai dengan permohonan suami. Bila tidak ada saksi-saksi yang benar-benar menyaksikan terjadinya pernikahan pada umumnya "ikrar" wanita itu dikuatkan

\footnotetext{
15 Taufik Hamami, Hukum Acara Perdata Agama, (Jakarta: PT. Tatanusa, 2004), hlm. 81

16 Aden Rosadi, Peradilan Agama Di Indonesia Dinamika Pembentukan Hukum, (Bandung: Simbiosa Rekatama Media, 2014), hlm. 194
} 
dengan dua saksi "istifadloh" yakni saksi yang mengetahui bahwa mereka adalah suami istri. ${ }^{17}$

Adapun syarat pengesahan Itsbat Nikah yakni diantaranya adalah:

a. Tidak bertentangan dengan Peraturan PerUndang-Undangan yang berlaku, khususnya Undang-Undang Nomor 1 Tahun 1974 tentang Perkawinan dan Kompilasi Hukum Islam (KHI).

b. Memenuhi syarat dan rukun nikah. Rukun dan syarat menentukan suatu perbuatan hukum, terutama yang menyangkut dengan sah atau tidaknya perbuatan tersebut dari segi hukum. Kedua kata tersebut mengandung arti yang sama dalam hal bahwa keduanya merupakan sesuatu yang harus diadakan. Dalam suatu acara perkawinan umpamanya rukun dan syaratnya tidak boleh tertinggal, dalam arti perkawinan tidak sah bila keduanya tidak ada atau tidak lengkap. Keduanya mengandung arti yang berbeda dari segi bahwa rukun itu adalah sesuatu yang berada di dalam hakikat dan merupakan bagian atau unsur yang mewujudkannya, sedangkan syarat adalah sesuatu yang berada di luarnya dan tidak merupakan unsurnya. Syarat itu ada yang berkaitan dengan rukun dalam arti syarat yang berlaku untuk setiap unsur yang menjadikan rukun. Ada pula syarat itu berdiri sendiri dalam arti tidak merupakan kriteria dari unsur-unsur rukun. ${ }^{18}$ Untuk melaksanakan perkawinan harus ada: calon suami; calon istri; wali nikah; dua orang saksi; serta ijab dan qabul.

c. Tidak melanggar larangan perkawinan. Dilarang melangsungkan perkawinan antara seorang pria dengan seorang wanita disebabkan: karena pertalian nasab; karena pertalian kerabat semenda; dan karena pertalian sesusuan.

d. Memenuhi persyaratan adminitrasi seperti kelengkapan identitas berupa Kartu Tanda Penduduk (KTP) dan Kartu Keluarga (KK) pada saat akan di sahkannya perkawinan oleh Pengadilan Agama.

\footnotetext{
${ }^{17}$ Zaini Ahmad Noeh, Peradilan Agama Islam Di Indonesia, (Jakarta: PT. Intermasa, 1980), hlm. 195

${ }^{18}$ Amir Syarifuddin, Loc. Cit., hlm. 59
} 
Bagir Manan, mantan Ketua Mahkamah Agung RI, menjelaskan bahwa dalam memahami status hukum perkawinan antarorang Islam di Indonesia, harus terlebih dahulu diketahui asas legalitas (Legality, beginsel) yang mendasari keberlakuan hukum perkawinan bagi orang Islam di Indonesia. asas legalitas berarti setiap perbuatan (tindakan) hukum harus atau wajib mempunyai dasar hukum tertentu yang telah ada sebelum perbuatan hukum itu dilakukan. suatu perbuatan hukum yang sah mengandung makna bahwa hubungan hukum dan akibat hukum menjadi sah pula. dalam perbuatan hukum yang sah sehubungan dengan dilakukannya perkawinan yang sah antara seorang laki-laki dengan seorang perempuan menunjukkan bahwa pasangan suami istri tersebut adalah sah, demikian pula dengan akibat hukum lainnya, misalnya terjadinya hubungan kekeluargaan yang berakibat timbulnya larangan perkawinan, dan juga terhadap harta kekayaan, maupun anak yang dilahirkan akibat perkawinan tersebut. ${ }^{19}$

Menurut Abdul Ghofur Anshori, dengan adanya Itsbat Nikah, seakan-akan membuka peluang untuk berkembangnya praktik nikah sirri, karena kalau ingin mensahkan perkawinannya tinggal ke Pengadilan Agama mengajukan permohonan Itsbat Nikah, akhirnya status pernikahannya pun menjadi sah di mata negara. Oleh karena itu, harus dipikirkan bagi hakim apakah dengan mengitsbatkan nikah tersebut akan membawa lebih banyak kebaikan atau justru mendatangkan mudharat bagi semua pihak dalam keluarga tersebut. Hal ini tidak boleh luput dari pertimbangan hakim dalam mengabulkan atau menolak permohonan Itsbat Nikah yang diajukan kepadanya. Namun demikian, sikap hakim dalam mengambil suatu keputusan bersifat bebas dengan pertimbangan dan menafsirkan pasal peraturan perundangan demi kemaslahatan dan keadilan bagi masyarakat. Seperti penafsiran Pasal 6 ayat (1) Kompilasi Hukum Islam yang menyatakan bahwa setiap perkawinan harus dilangsungkan di hadapan dan di bawah pengawasan Pegawai Pencatat Nikah dan pada ayat (2) disebutkan bahwa perkawinan yang dilangsungkan di luar pengawasan Pegawai Pencatat Nikah tidak mempunyai kekuatan hukum. ${ }^{20}$

\footnotetext{
${ }^{19}$ Muhammad Syaifuddin, Sri Turatmiyah dan Annalisa Yahanan, Loc. Cit,. hlm. 272

${ }^{20}$ Muhammad Syaifuddin, Op. Cit
} 
Bagir manan menguraikan pendapatnya bahwa meskipun masalah pencatatan perkawinan telah tersosialisasikan cukup lama dalam Pasal 2 ayat (2) UU Nomor 1 Tahun 1974 maupun Pasal 5 dan Pasal 6 Kompilasi Hukum Islam, tetapi sampai pada saat ini masih dirasakan adanya kendala dalam pelaksaannya. Hal ini mungkin sebagian masyarakat muslim ada yang berpegang teguh kepada perspektif Fiqh tradisional. pemahaman mereka perkawinan sudah sah apabila ketentuan-ketentuan yang tersebut dalam kitab-kitab Fiqh sudah terpenuhi, tidak perlu ada pencatatan di KUA. ${ }^{21}$

\section{Batalnya Itsbat Nikah}

Perkara Itsbat Nikah yang sejak lama ada di Pengadilan Agama adalah analogi yang salah kaprah, khusus mengenai perkara Itsbat Nikah tidak berdampak sistemik kepada pasal-pasal lainnya dalam Peraturan PerUndangUndangan perkawinan. Karena Undang-Undang Perkawinan menyatakan suatu perkawinan sah jika dilakukan menurut hukum masing-masing agamanya dan kepercayaannya itu, hanya saja tiap-tiap perkawinan dicatat menurut Peraturan Perundang-undangan yang berlaku. Berdasarkan ketentuan itu, tentu logis saja jika ada orang yang sebelumnya telah melangsungkan perkawinan sesuai dengan hukum agamanya, kemudian karena belum mencatatkan perkawinannya, memohonkan Itsbat Nikah untuk mencatatkan perkawinannya, karena mencatatkan perkawinan bukan syarat sahnya suatu perkawinan. ${ }^{22}$ Perkawinan yang tidak dicatat oleh pejabat yang berwenang karena suatu alasan yang dibenarkan oleh hukum, maka dapat ditetapkan oleh Pengadilan setempat (Itsbat Nikah). ${ }^{23}$

Batalnya Itsbat Nikah sama halnya dengan batalnya suatu perkawinan. Dalam Kompilasi Hukum Islam di sebutkan bahwa perkawinan batal apabila perkawinan dilakukan antara dua orang yang mempunyai hubungan darah, semenda dan sesusuan.

\footnotetext{
${ }^{21}$ Muhammad Syaifuddin, Op. Cit., hlm. 270-271

${ }^{22}$ Aris Bintania, Hukum Acara Peradilan Agama Dalam Kerangka Figh Al-Qadha, (Jakarta: Raja Grafindo Persada, 2012), hlm. 164

${ }^{23}$ Aden Rosadi, Loc. Cit., hlm. 198
} 
Suatu perkawinan dapat dibatalkan apabila:

a. Seorang suami melakukan poligami tanpa izin Pengadilan Agama;

b. Perempuan yang dikawini ternyata kemudian diketahui masih menjadi isteri pria lain yang mafqud;

c. Perempuan yang dikawini ternyata masih dalam iddah dari suami lain;

d. Perkawinan yang melanggar batas umur perkawinan sebagaimana ditetapkan dalam Pasal 7 Undang-Undang Nomor 1 Tahun 1974;

e. Perkawinan dilangsungkan tanpa wali atau dilaksanakan oleh wali yang tidak berhak;

f. Perkawinan yang dilaksanakan dengan paksaan.

Batalnya perkawinan menurut Undang-Undang Nomor 1 Tahun 1974 Pasal 22 yakni perkawinan dapat dibatalkan apabila para pihak tidak memenuhi syaratsyarat untuk melangsungkan perkawinan.

\section{Pendapat Ahli Hukum Terkait Larangan Itsbat Nikah Pasca Berlakunya Undang-Undang Perkawinan}

Sebagaimana telah diuraikan bahwa perkawinan yang sah menurut Pasal 2 ayat (1) Undang-Undang Nomor 1 Tahun 1974 tentang Perkawinan adalah perkawinan yang dilakukan menurut hukum agama. Perkawinan yang dilakukan menurut Hukum Agama adalah suatu "peristiwa hukum” yang tidak dapat dianulir oleh Pasal 2 ayat (2) Undang-Undang Nomor 1 Tahun 1974 tentang Perkawinan, yang menentukan tentang "pencatatan perkawinan". ${ }^{24}$

Itsbat Nikah sebagai pengesahan perkawinan tidak berarti perkawinan yang telah dilaksanakan suami dan istri tidak sah sepanjang memenuhi rukun dan syarat perkawinan menurut hukum Islam. Itsbat Nikah adalah proses hukum yang harus ditempuh oleh pasangan suami dan istri di Pengadilan Agama, agar "perkawinan tidak dicatat" yang telah sah menurut hukum agama (islam), tetapi kemudian menjadi "perkawinan dicatat" secara hukum negara. ${ }^{25}$

\footnotetext{
${ }^{24}$ Neng Djubaidah, Loc. Cit

${ }^{25}$ Muhammad Syaifuddin, Sri Turatmiyah dan Annalisa Yahanan, Loc. Cit
} 
Perkara Itsbat Nikah (permohonan untuk disahkan suatu perkawinan) adalah perkara voluntair yang diajukan oleh pihak yang berkepentingan ke Pengadilan, agar perkawinannya dapat dinyatakan sah secara hukum. Ketentuan tentang Itsbat Nikah dapat dilihat dalam penjelasan Pasal 49 ayat (2) angka 22 UU Nomor 7 tahun 1989 tentang peradilan Agama disebutkan, "Yang dimaksud dengan bidang perkawinan yang diatur dalam UU Nomor 1 Tahun 1974 tentang Perkawinan antara lain adalah, pernyataan tentang sahnya perkawinan yang terjadi sebelum UU Nomor 1 Tahun 1974 tentang Perkawinan”. ${ }^{26}$

Dari ketentuan pasal ini dapat ditarik garis hukum, bahwa hanya dua macam perkawinan saja yang dapat dimohonkan Itsbat Nikah ke Pengadilan, pertama, perkawinan yang dilakukan secara sah yang memenuhi syarat materiil (norma agama) sebagaimana diatur dalam Pasal 2 ayat (1) UU Perkawinan; kedua, adalah perkawinan yang dilakukan sebelum tahun 1974. Bagi pasangan suami istri yang melaksanakan perkawinan yang telah memenuhi syarat materiil sebelum tahun 1974 tetapi tidak memiliki akta nikah, apakah karena musnah, hilang, atau karena sebab lain sehingga tidak memiliki surat nikah, dapat mengajukan permohonan Itsbat Nikah ke Pengadilan yang daerah hukumnya mewilayahi tempat tinggal pemohon. Dengan demikian, secara a contrario menurut pasal tersebut, perkawinan yang dilaksanakan secara sirri atau di bawah tangan setelah tahun 1974, tidak dapat diajukan pengesahan nikah ke Pengadilan. ${ }^{27}$

Adapun perkawinan yang dilakukan secara sirri atau di bawah tangan (tidak dicatatkan) tetapi telah memenuhi ketentuan Pasal 2 ayat (1) UU Nomor 1 Tahun 1974 yang dilaksanakan setelah tahun 1974 dimana situasi negara atau daerah tempat perkawinan dilaksanakan kondusif serta Kantor Pencatat Nikah berfungsi sebagaimana biasa, maka perkawinan semacam ini tidak dapat dimohonkan Itsbat Nikah (pengesahan nikah) ke Pengadilan, juga tidak dapat didaftarkan ke Kantor Pencatat Nikah untuk dicatatkan. Sebab tidak dipenuhinya ketentuan Pasal 2 ayat (2) tersebut bukan karena situasi atau kondisi yang memaksanya sehingga perkawinannya tidak dapat dicatatkan ke Kantor Pencatat Nikah, melainkan

\footnotetext{
${ }^{26}$ Anshari, Loc. Cit

27 Anshari, Loc. Cit
} 
karena lebih ditentukan oleh faktor ketidaktaatan kedua calon mempelai terhadap hukum alias tidak patuh hukum. Dan terhadap orang yang tidak patuh hukum, maka perbuatan hukum yang dilakukannya tersebut layak untuk tidak mendapat perlindungan hukum (no legal protect), dan hukum memandangnya sebagai perbuatan yang tidak mempunyai kekuatan hukum (no legal force), sebagaimana bunyi Pasal 6 ayat (2) Kompilasi Hukum Islam, "Perkawinan yang dilakukan di luar pengawasan Pegawai Pencatat Nikah tidak mempunyai kekuatan hukum”.

Perkawinan yang dapat dimohonkan Itsbat Nikah ke pengadilan hanyalah perkawinan yang sah yang dilakukan sebelum tahun 1974, maka pengadilan harus menyatakan tidak berwenang mengitsbatkannya karena tidak mempunyai dasar hukum. Dan jika pun Pengadilan mengitsbatkannya, maka Penetapan Pengadilan tersebut harus dinyatakan batal demi hukum (van rechtswege). ${ }^{28}$

Dalam ayat (2) disebutkan: "Dalam hal perkawinan tidak dapat dibuktikan dengan akta nikah, dapat diajukan Itsbat nikahnya ke Pengadilan Agama”. Pada ayat (3) disebutkan: Itsbat nikah yang diajukan ke Pengadilan Agama terbatas mengenai hal-hal yang berkenaan dengan; (a) Adanya perkawinan dalam rangka penyelesaian perceraian; (b) Hilangnya akta nikah; (c) Adanya keraguan tentang sah atau tidaknya salah satu syarat perkawinan; (d) Adanya perkawinan yang terjadi sebelum berlakunya Undang-Undang Nomor 1 Tahun 1974 dan; (e) Perkawinan yang dilakukan oleh mereka yang tidak mempunyai halangan perkawinan menurut Undang-Undang Nomor 1 Tahun 1974.

Dalam Kompilasi Hukum Islam Pasal 4 disebut sahnya perkawinan bila dilakukan menurut Hukum Islam. Pada Pasal 5 ditegaskan bahwa setiap perkawinan harus dicatat oleh Pegawai Pencatat Nikah. Karena itu, dalam Pasal 6 dinyatakan bahwa setiap perkawinan harus dilangsungkan di hadapan dan di bawah pengawasan Pegawai Pencatat Nikah. Dan perkawinan yang dilakukan di luar pengawasan pencatat nikah tidak mempunyai kekuatan hukum. Di dalam Pasal 7 disebutkan bahwa perkawinan hanya dapat dibuktikan dengan Akta Nikah yang dibuat oleh Pegawai Pencatat Nikah. ${ }^{29}$ Dalam Pasal 7 ayat 2 dan seterusnya

\footnotetext{
${ }^{28}$ Anshari, Loc. Cit

${ }^{29}$ Mohammad Daud Ali, Loc. Cit
} 
dimungkinkan bagi mereka membuktikan perkawinannya dengan Akta Nikah dapat mengajukan "Itsbat Nikah" nya ke Pengadilan Agama. ${ }^{30}$

Status perkawinan dalam hal ini diartikan dengan keadaan dan kedudukan perkawinan yang telah dilangsungkan. Dalam aspek ini sebenarnya UndangUndang telah memberikan rumusan tentang perkawinan yang sah. Pasal 2 Ayat 1 Undang-Undang Nomor 1 Tahun 1974 Tentang Perkawinan menyebutkan bahwa perkawinan adalah sah, apabila dilakukan menurut hukum masing-masing agamanya dan kepercayaannya itu. Dalam penjelasan Pasal 2 disebutkan bahwa dengan perumusan pada Pasal 2 Ayat (1) ini, tidak ada Perkawinan diluar hukum rnasing-masing agamanya dan kepercayaannya itu, sesuai dengan UndangUndang Dasar 1945. Yang dimaksud dengan hukum masing-masing agamanya dan kepercayaannya itu termasuk ketentuan PerUndang-Undangan yang berlaku bagi golongan agamanya dan kepercayaannya itu sepanjang tidak bertentangan atau tidak ditentukan lain dalam Undang-Undang ini. Berdasarkan ketentuan Pasal 2 Ayat 1 Undang-Undang Perkawinan dan penjelasannya ini, dapat diketahui bahwa patokan untuk mengetahui suatu perkawinan sah adalah hukum masingmasing agama dan kepercayaan para pihak serta ketentuan PerUndang-Undangan yang berlaku sepanjang tidak bertentangan atau tidak ditentukan lain dalam Undang-Undang Perkawinan. Pasal 2 Ayat (2) menyebutkan bahwa tiap-tiap perkawinan dicatat menurut Peraturan PerUndang-Undangan yang berlaku. Pencatatan perkawinan akan menimbulkan kemaslahatan umum karena dengan pencatatan ini akan memberikan kepastian hukum terkait dengan hak-hak suami/isteri, kemaslahatan anak maupun efek lain dari perkawinan itu sendiri. Perkawinan yang dilakukan di bawah pengawasan atau di hadapan Pegawai Pencatat Nikah/Kantor Urusan Agama akan mendapatkan Akta Nikah sebagai bukti telah dilangsungkannya sebuah perkawinan.

Menurut Abdul Ghofur Anshori, dengan adanya Itsbat Nikah, seakan-akan membuka peluang untuk berkembangnya praktik nikah sirri, karena kalau ingin mensahkan perkawinannya tinggal ke Pengadilan Agama mengajukan permohonan Itsbat Nikah, akhirnya status pernikahannya pun menjadi sah di mata

\footnotetext{
${ }^{30}$ Abdurrahman, Loc. Cit
} 
negara. Oleh karena itu, harus dipikirkan bagi hakim apakah dengan mengitsbatkan nikah tersebut akan membawa lebih banyak kebaikan atau justru mendatangkan mudharat bagi semua pihak dalam keluarga tersebut. Hal ini tidak boleh luput dari pertimbangan hakim dalam mengabulkan atau menolak permohonan Itsbat Nikah yang diajukan kepadanya. Namun demikian, sikap hakim dalam mengambil suatu keputusan bersifat bebas dengan pertimbangan dan menafsirkan pasal peraturan perundangan demi kemaslahatan dan keadilan bagi masyarakat. Seperti penafsiran Pasal 6 ayat (1) Kompilasi Hukum Islam yang menyatakan bahwa setiap perkawinan harus dilangsungkan di hadapan dan di bawah pengawasan Pegawai Pencatat Nikah dan pada ayat (2) disebutkan bahwa perkawinan yang dilangsungkan di luar pengawasan Pegawai Pencatat Nikah tidak mempunyai kekuatan hukum.

Lebih lanjut, Abdul Ghofur Anshori menjelaskan bahwa tidak mempunyai kekuatan hukum atau kelemahan hukum tidak berarti bahwa hal itu sebagai suatu perkawinan yang tidak sah atau batal demi hukum. Pemikiran ini didasari pada pemahaman terhadap UU Nomor 1 Tahun 1974 jo. PP Nomor 9 Tahun 1975 dan Kompilasi Hukum Islam, dengan interpretasi bahwa yang menjadi patokan keabsahan suatu perkawinan itu adalah dilaksanakan berdasarkan hukum agama (Islam). Tidak ada satu pasal pun yang menyatakan tidak sah atau batal demi hukum terhadap perkawinan yang di langsungkan di luar pengawasan Pegawai Pencatat Nikah.

\section{Ijtihad Majelis Hakim Terkait Penetapan Pengadilan yang Mengesahkan}

\section{Itsbat Nikah Pasca Berlakunya Undang-Undang Perkawinan}

Berdasarkan ketentuan terkait alasan-alasan untuk mengajukan Itsbat Nikah yakni diatur oleh Kompilasi Hukum Islam Pasal 7 dan Undang-Undang Nomor 1 Tahun 1974 tentang kewajiban pencatatan perkawinan. Setiap perkawinan itu harus mempunyai buku nikah, jika tidak mempunyai buku nikah dapat diajukan Itsbat Nikah nya ke Pengadilan. Dalam Pasal 7 Kompilasi Hukum Islam dijelaskan pada huruf (e) bahwa Itsbat Nikah dilakukan karena dalam rangka perceraian, hilang atau rusaknya buku nikah, adanya perkawinan yang 
dilangsungkan sebelum tahun 1974, kemudian disebutkan juga bahwa perkawinan yang dilangsungkan tidak melanggar Peraturan PerUndang-Undangan.

Jadi pada dasarnya jika terdapat perkawinan yang dilakukan secara dibawah tangan setelah tahun 1974, Majelis Hakim memeriksa terlebih dahulu didalam sidang Itsbat Nikah, apakah perkawinannya itu telah sesuai dengan rukun dan syarat sesuai syariat Islam dan hukum positif yang berlaku di Indonesia. Jika terdapat peraturan atau pasal-pasal yang mendukung untuk diitsbatkannya perkawinan tersebut, maka dapat digunakan sebagai penguat dalam suatu penetapan. Majelis Hakim mengabulkan permohonan pengesahan Itsbat Nikah tersebut karena lebih melihat kepada sisi kemaslahatannya, dan juga perlunya kepastian dan perlindungan hukum terhadap anak-anak para Pemohon. ${ }^{31}$

Namun karena Itsbat Nikah sangat dibutuhkan oleh masyarakat, maka hakim Pengadilan Agama melakukan "ijtihad" dengan menyimpangi tersebut, kemudian mengabulkan permohonan Itsbat Nikah berdasarkan ketentuan Pasal 7 Ayat (3) huruf e Kompilasi Hukum Islam, Apabila perkawinan yang dimohonkan untuk diitsbatkan itu tidak ada halangan perkawinan sebagaimana diatur di dalam Undang-Undang Nomor 1 Tahun 1974 tentang Perkawinan, maka Pengadilan Agama akan mengabulkan permohonan Itsbat Nikah meskipun perkawinan itu dilaksanakan pasca berlakunya Undang-Undang Nomor 1 Tahun 1974 tentang Perkawinan. Oleh karena itu, penetapan Itsbat Nikah oleh Pengadilan Agama tersebut, tidak lebih hanya sebagai kebijakan untuk mengisi kekosongan hukum yang mengatur tentang Itsbat Nikah terhadap perkawinan yang dilaksanakan pasca berlakunya Undang-Undang Nomor 1 Tahun 1974 tentang Perkawinan.

Kebijakan tersebut diambil karena ternyata Itsbat Nikah oleh Pengadilan Agama itu karena pertimbangan mashlahah bagi umat Islam. Itsbat Nikah sangat bermanfaat bagi umat Islam untuk mengurus dan mendapatkan hak-haknya yang berupa surat-surat atau dokumen pribadi yang dibutuhkan dari instansi yang berwenang serta memberikan jaminan perlindungan kepastian hukum terhadap masing-masing pasangan suami istri, termasuk perlindungan terhadap status anak

\footnotetext{
${ }^{31}$ Hasil wawancara dengan Ketua Majelis Hakim Pengadilan Agama Tigaraksa Ibu Musidah
} 
yang lahir dari perkawinan itu, dan perlindungan terhadap akibat hukum yang akan muncul kemudian.

\section{Penutup}

Peraturan tentang disahkannya suatu perkawinan (Itsbat Nikah) telah jelas disebutkan dalam Peraturan PerUndang-Undangan yang berlaku, yakni UndangUndang Nomor 1 Tahun 1974 Tentang Perkawinan dan Kompilasi Hukum Islam. Tetapi pada kenyaataannya terdapat masyarakat yang tidak taat hukum karena masih banyaknya masyarakat yang melakukan perkawinan tidak di bawah pengawasan Pegawai Pencatat Nikah. Selain itu, hal lain yang juga menjadi penyebabnya adalah ketidaktahuan masyarakat mengenai hukum dikarenakan masih banyaknya masyarakat yang awam dan buta terhadap aturan hukum terkait perkawinan yang memiliki dampak yang begitu besar terhadap perkembangan hukum di Indonesia.

Masih banyaknya masyarakat yang menganggap tidak pentingnya suatu pencatatan perkawinan, ini mengakibatkan semakin menjamurnya praktik nikah di bawah tangan dalam hal ini disebut sebagai nikah sirri. Dalam hal terkait Penetapan yang dilakukan oleh Majelis Hakim di Pengadilan Agama Tigaraksa yakni mengenai perkara pengesahan perkawinan yang dilakukan pasca berlakunya Undang-Undang Nomor 1 Tahun 1974 tentang Perkawinan ini seolah-olah membuka kembali peluang kepada masyarakat untuk melakukan perkawinan tidak di bawah pengawasan Pegawai Pencacat Nikah.

Setelah melakukan beberapa tahap wawancara dengan Ketua Majelis Hakim yang mengabulkan permohonan Itsbat Nikah tersebut, akhirnya peneliti mendapatkan suatu pemahaman terhadap Penetapan Itsbat Nikah yang dilakukan pasca berlakunya Undang-Undang Nomor 1 Tahun 1974 Tentang Perkawinan. Dari sinilah teori keadilan digunakan sebagai suatu hal yang penting agar hakim dapat berlaku adil dalam menegakkan keadilan tanpa memandang stratifikasi sosial dengan tetap mempertimbangkan sisi kebaikan dan mudharatnya. Dapat dilihat dengan jelas bahwa peran Majelis Hakim sangat penting dalam menetapkan suatu perkara dengan melakukan ijtihad dan lebih mementingkan 
kemaslahatannya, tetapi tetap tidak menyimpang dan keluar dari peraturan yang berlaku yang dapat berpengaruh terhadap suatu Penetapan Pengadilan.

\section{DAFTAR PUSTAKA}

Abdurrahman. Kompilasi Hukum Islam Di Indonesia. (Jakarta: Akademika Pressindo, 2010).

Ali, Mohammad Daud. Hukum Islam. (Jakarta: PT. Raja Grafindo Persada, 2004).

Ali, Zainuddin Ali. Hukum Perdata Islam Di Indonesia. (Jakarta: Sinar Grafika, 2012).

Anshary. Kedudukan Anak Dalam Perspektif Hukum Islam Dan Hukum Nasional. (Bandung: CV. Mandar Maju, 2014).

Bintania, Aris. Hukum Acara Peradilan Agama Dalam Kerangka Fiqh Al-Qadha. (Jakarta: Raja Grafindo Persada, 2012).

Hamami, Taufik. Hukum Acara Perdata Agama. (Jakarta: PT. Tatanusa, 2004).

Harahap, M. Yahya Harahap. Kedudukan Kewenangan dan Acara Peradilan Agama. Cet. III. (Jakarta: Pustaka Kartini, 1997).

Mubarok, Jaih. Peradilan Agama di Indonesia. (Jakarta: Pustaka Bani Quraish, 2004).

Noeh, Zaini Ahmad. Peradilan Agama Islam Di Indonesia. (Jakarta: PT. Intermasa, 1980).

Rosadi, Aden. Peradilan Agama Di Indonesia Dinamika Pembentukan Hukum. (Bandung: Simbiosa Rekatama Media, 2014).

Syarifuddin, Amir. Hukum Perkawinan Islam Di Indonesia. (Jakarta: Kencana Prenada Media Group, 2011).

Syarifuddin, Muhammad; Sri Turatmiyah dan Annalisa Yahanan. Hukum Perceraian. (Jakarta: Sinar Grafika, 2013).

Zuhriah, Erfaniah Zuhriah. Peradilan Agama di Indonesia. (Malang: UIN Malang Press, 2008). 